\title{
Intermédialités
}

Histoire et théorie des arts, des lettres et des techniques

Intermediality

History and Theory of the Arts, Literature and Technologies

\section{“There is a strong visual component in radio". Glenn Gould in conversation with John Thompson}

Numéro 19, printemps 2012

URI : https://id.erudit.org/iderudit/1012664ar

DOI : https://doi.org/10.7202/1012664ar

Aller au sommaire du numéro

Éditeur(s)

Revue intermédialités (Presses de l’Université de Montréal)

ISSN

1705-8546 (imprimé)

1920-3136 (numérique)

Découvrir la revue

Citer ce document

(2012). "There is a strong visual component in radio". Glenn Gould in conversation with John Thompson. Intermédialités / Intermediality, (19), 181-187. https://doi.org/10.7202/1012664ar

\section{Résumé de l'article}

L'entretien inédit publié ici est extrait d'un document vidéo inachevé, Radio as Music, produit par Glenn Gould en 1975. Celui-ci y explique sa vision programmatique d'un type de musicalité spécifique à la radio et laisse entrevoir, à travers ses essais vidéo pour la télévision, combien il fut, avant la lettre, un artiste intermédial. La seule partie de la bande qui ait été montée documente une séance de studio dans laquelle Gould et son collaborateur, le technicien Donald Logan, travaillent au mixage de la pièce radio Quiet in the Land. Le producteur John Thompson questionne alors le musicien sur sa conception des « documentaires radio contrapuntiques ». Radio as Music est un document unique non seulement parce que Gould y explicite sa technique de composition, mais aussi parce qu'il en pointe le mode de production concret et en fait entendre les conséquences dans le détail « musical ». (Voir « Radio as Music. A Video Document by [and with] Glenn Gould », introduction de Philippe Despoix.) 


\section{"There is a strong visual component in radio"}

\section{GlenN Gould in conversation with JOHN THOMPSON*}

John Thompson: Glenn, I've been watching you work here while we were getting set up and I'm really amazed how you relate all your audio work problems in video terminology.

Glenn Gould: It's true, I do.

JT: Are you really a frustrated film director?

GG: Well, that too, I certainly am, John. But to quote back at you the oldest cliché in the radio business, there is a very strong visual component in radio after all.

JT: Sure, but I would have thought that the visual component grabbed at the listener's imagination rather than at the producer's ability to offer explicit detail.

GG: Hm, well I think that's true, John, it's certainly true in monaural broadcasting. That is another old cliché, [which is] that the radio is a monaural medium and, in some sense, I must say I believe that too. I think the imagination-the listener's imagination-can function superbly when it is presented with what you could call an entanglement of "center-image-data" alias "mono." It could, with that data, select its own points of emphasis. It could decide what's important and what's less important and so forth and so on, to have a whole set of relationships going in the imagination. But when you go to stereo, which is a much more explicit mode-and the problems are certainly comparable when you go to 36 o degree sound, no question - , you begin to isolate certain data, you decide that this goes on the right, and this goes on the left or whatever. And the moment you do that, you've taken away certain of the prerogatives of the listener's imagination, you're doing a lot of the listener's work for him and I think it's very

"The following dialogue is taken from Radio as Music, an unreleased video produced privately by Glenn Gould on August 29, 1975, in the Canadian Broadcasting Corporation's film house, with technician Donald Logan and freelance producer John Thomson (Fig. 1-4). Transcription (o'3"34 to o'12" 05 ) by Caroline Bem. We wish to thank the CBC for permission to print this document. 

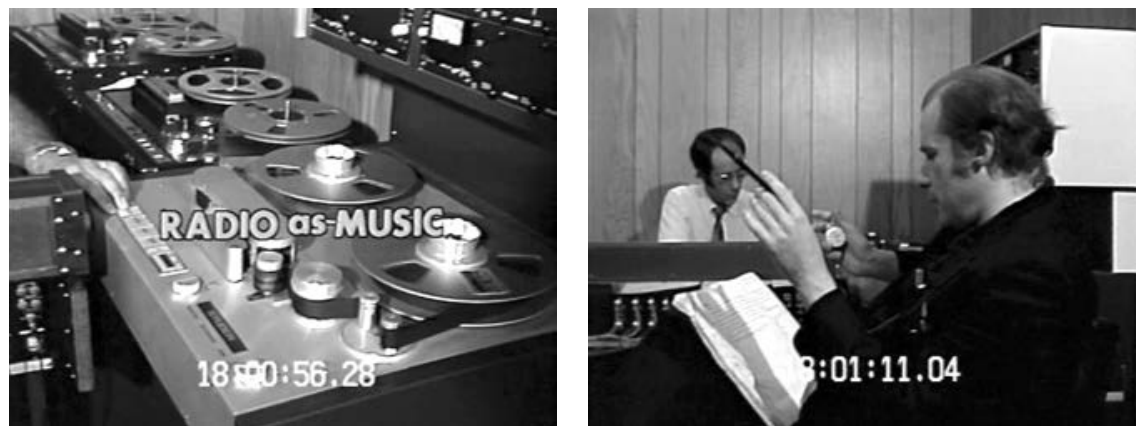

Figs. 1 \& 2: Radio as Music (Glenn Gould, 1975) produced in the CBC's film house (left); Gould with technician Donald Logan mixing the radio piece Quiet in the Land (right) (C) CBC.

182 doubtful that you can ever fully satisfy his expectations as his imagination would have done. So what you must do in compensation, as I see it, in stereo, is to offer an absolutely iron-clad alibi for everything that happens on the stereo screen: every silent source, every character, has to have an alibi to make a movement at all. To move an inch on the screen is a major adjustment, because it's a major compromise with the listener's imagination. Since stereo does give you the opportunity to use multiple data-to have a multiplication of data if you have a great deal of information at one time, which you can't really have in mono with the same success and the same succinctness - the only thing that you can hope for is that the listener will somehow cut through all that multiplication of data and still manage to find real work for his imagination.

JT: Well this brings up another point. Everything that you've done in radio has managed to upset and even enrage certain people who feel that radio is not only a monaural medium perhaps, but also a monophonic one, which is to say that one ought not to allow more than one primary voice at a time. But in all your major radio pieces there appears to be a very... one might almost say, a Germanic emphasis on counterpoint [GG laughs]. You seem to want to have two or three or four voices running simultaneously, and with various background effects or musical effects accompanying them. And I've had the same problem with some of your busier radio pieces. And it's, sort of, well, like Ives's Fourth Symphony. Do you know what I'm talking about?

GG: I know what you're trying to say. But I'd have to quarrel with that Ives example. It seems to me that Ives's Fourth Symphony is a great example of musical actuality, but I think we ought to distinguish between actuality and realism. ${ }^{1}$ I

1. For Gould's analysis of this work, see “The Ives Fourth," Musical America, July 1965 , reprinted in Tim Page (ed.), The Glenn Gould Reader, New York, Random House, p. 185-189. 

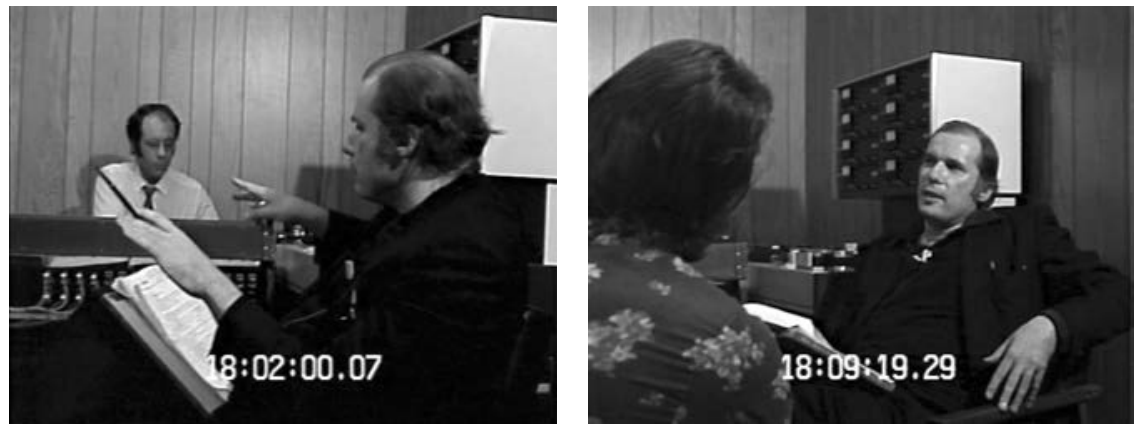

Figs. 3 \& 4: Gould with technician Donald Logan mixing the piece Quiet in the Land (left); Gould in conversation with freelance producer John Thompson (right) (C) CBC.

think that you can control a very realistic environment, that you can have a measure of editorial control over a realistic environment. The moment you get to a genuine actuality, as I understand it, you've got to introduce some sort of aleatoric element, which I don't really want.

JT: You don't think of yourself as an aleatoricist?

GG: Oh, God no. Not for a moment, no. Can I suggest a musical analogy in lieu of your Ives example?

JT: Sure.

GG: Well, it would be Webern, believe it or not.

JT: Really? His textures are not a little too sanitized and isolated?

GG: That's true, they certainly are, and I guess I have a compulsion to keep busy, texturally, so consequently I must be a spiritual descendant of Max Reger or something [JT laughs]. But let me come back to the Webern analogy because I really think it holds. In all of Webern's later work, if I understand it, he tried to introduce in his tone rows a kind of double-entendre capability. ${ }^{2}$ It would be a very close, but not exact, imitation. Well, you know the kind of thing I'm talking about, where there's, let's say, a G-sharp and a B-flat [sings interval] in the violin and it's suddenly imitated, or almost imitated, by a [makes a sound] G-sharp and a B-natural on the alto sax or whatever. Well, in the same way-if I can let the ego hang out for a moment-I think if you will examine those busy pieces that you've complained about in my radio work, you'll find that every line is meant, at least, to stack up with every line opposite. So that there is, indeed, a great deal of data, a great deal of information being given, but that the lines are intended to

2. See, for example, Gould's Introduction to Webern's Konzert für neun Instrumente, op. 24 (1934) in his TV broadcast, Musicamera: Music In Our Time. The Artist as Artisan, 1930-40, December 1977. 

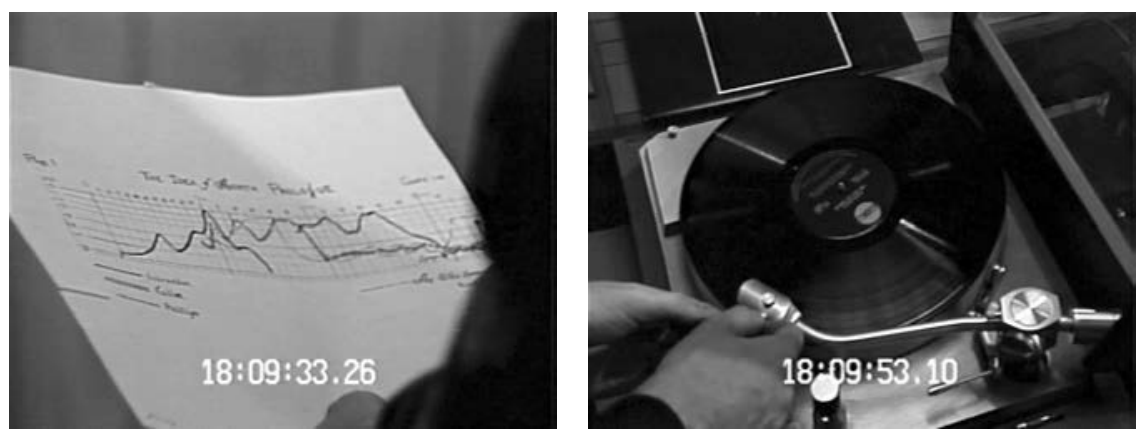

Figs. 5 \& 6: Sketch for the prologue to the radio piece The Idea of North (left); listening to the prologue to the same radio piece (right) (C) CBC.

184 contradict each other and to supplement each other in some fashion, to make use of the same basic terminology, set of numbers, similar identical terms, whatever. They have a relationship.

JT: Can you illustrate that?

GG: I wish this piece, The Mennonites, ${ }^{3}$ was finished, because there's going to be a scene in there which will drive you crazy if you've had trouble with the other pieces. It's a scene in which nine characters stand around and talk about the Church's relationship with pacifism at what appears to be a church meeting-it's all hooked up from the 8-track of course-but in any event it is going to make everything I've done up till the present seem like Gregorian chant by comparison, but I can't use it since it's not finished, so let me take something that is not only simpler, but is, in fact, also monaural. It's the prologue to The Idea of North and, by the way, from an engineer's standpoint, this is what it looks like (Fig. 5). ${ }^{4}$

JT: Each of these lines represents one character, does it?

GG: It does. It's a trio sonata, musically speaking. So there are three characters involved, which is logical for a trio sonata I guess.

JT: I guess so.

GG: And there's a government official, a sociologist, and in one moment, a nurse, whose first words of wisdom we shall shortly hear. Speak to us, nurse(Fig. 6)! [Playing record, the nurse, Marianne Schroeder begins speaking in background]

3. Working title of The Quiet in the Land, produced by Gould in association with the CBC; technical supervision: Donald Logan, assisted by John Jessop and Stan Evanyshyn (first broadcast in March 1977).

4. The Idea of North, production: Glenn Gould; coordination: Janet Sommerville; technical supervision: Lorne Tulk (first broadcast as part of CBC's Ideas program). 

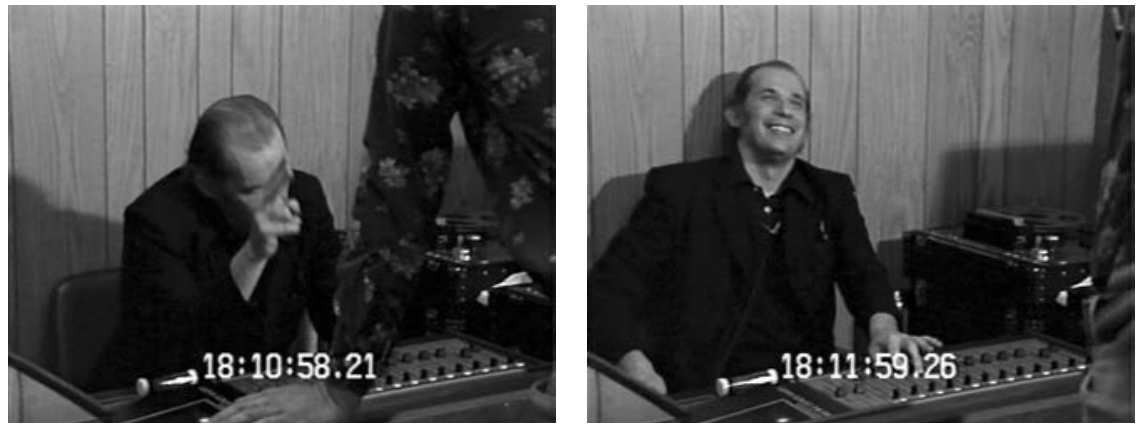

Figs. $7 \&$ 8: Gould cuing the entry of one of the voices in The Idea of North (left); Gould at mixing desk still in conversation with John Thompson (right) (C) CBC.

Voice of Marianne Schroeder: I was fascinated by the country as such. I flew north from Churchill to Coral Harbor...

GG: There she goes... And the whole scene is built as a long crescendo and an equally long diminuendo on an interchange between these three voices. She starts solo, she gives us her visual impressions of flying over Hudson's Bay and then she's joined by the other two characters, one at a time. The peak of the scene is reached at the mid-point of the third voice. [voice of MS in background: ... and you could see the bottom of the lakes, and it was a most fascinating experience...] And she goes on in this fashion for some time.

Voice of MS: I remember I was up in the cockpit with the pilot...

GG: It's a very visual commentary. [... and I was forever looking out, left and right...] That's where you gotta have stereo. This is a mono product...

JT: When was it made?

GG: Sixty-seven.

JT: So that was before there was stereo.

GG: Right.

Voice of MS: ... and I was always looking for a polar bear, or some seals that I could spot, but unfortunately, there were none.

GG: And in a moment now, she's joined by the second voice.

Voice of MS: And as we flew along the east coast of Hudson's Bay, this flat, flat country.

[GG precisely cues the sociologist Frank Vallee's entry through an emphatic gesture of the hand (Fig. 7)]

Voice of Frank Vallee: I don't go-let me say this, I don't go for this northmanship bit at all...

5. All voice transcriptions and names are taken from the original transcript of Gould's 1967 radio play as printed in "Prologue from 'The Idea of North", in Tim Page (ed.), The Glenn Gould Reader, New York, Random House, 1984, p. 389-39o. 
Voice of MS: Frightened me a little, because it just seemed endless. We seemed to be going to nowhere.

GG: And then in a moment, she says something about their going further north.

Voice of MS: ... and the further north we went...

GG: And he says, "farther north." [Voice of FV in background] And they exchange on those two words [GG adds emphasis through hand gesture]. Except that he says it in a somewhat cynical fashion.

JT: Whereas she's really the idealist.

GG: Exactly. And at the moment of interchange, he now becomes of course the dominant voice. [Voice of FV still in background.] And then in a moment he says this thing about 22 days and 30 days and then this voice [the government official Robert Phillips] says "I served the department for 11 years..."

JT: And the exchange occurs almost exactly.

GG: Yes, exactly.

Voice of Robert Phillips: ...conceive of anyone being in close touch with the North, whether they lived there all the time...

GG: And then the government official here goes on about his preoccupation with his duties and the sociologist comments on what he's just been saying, cynical as ever.

Voice of RP: When I left in 1965, at least left the job there, it wasn't because of...

Voice of FV: ... as though there's some special merit, some virtue, to being in the North...

GG [chuckles]: And then on the way down, they-instead of commenting on numbers and details of this kind, they begin to react to each other it seems. Then finally, this guy asks the crucial question [GG cues, voices in background]

JT: And then the nurse responds.

GG: And appears to answer his question. And then gradually they all go onto a tape loop and dissolve into the background and you get the opening credits.

JT: [laughs] Can we hear that again?

GG: Yes, why don't we look at the film version?

JT: Why not?

GG: Indeed, it went right to the heartbeat, it didn't deviate for a syllable.

JT: So you're very happy with the film translation.

GG: Happy with that sequence in particular, it becomes a sextet instead of a trio. The camera has its own three images going and it is treated subjectively, it's the eyes of the nurse, the bureaucrat and the sociologist. Five, four, three, two, one. [Film starts] 

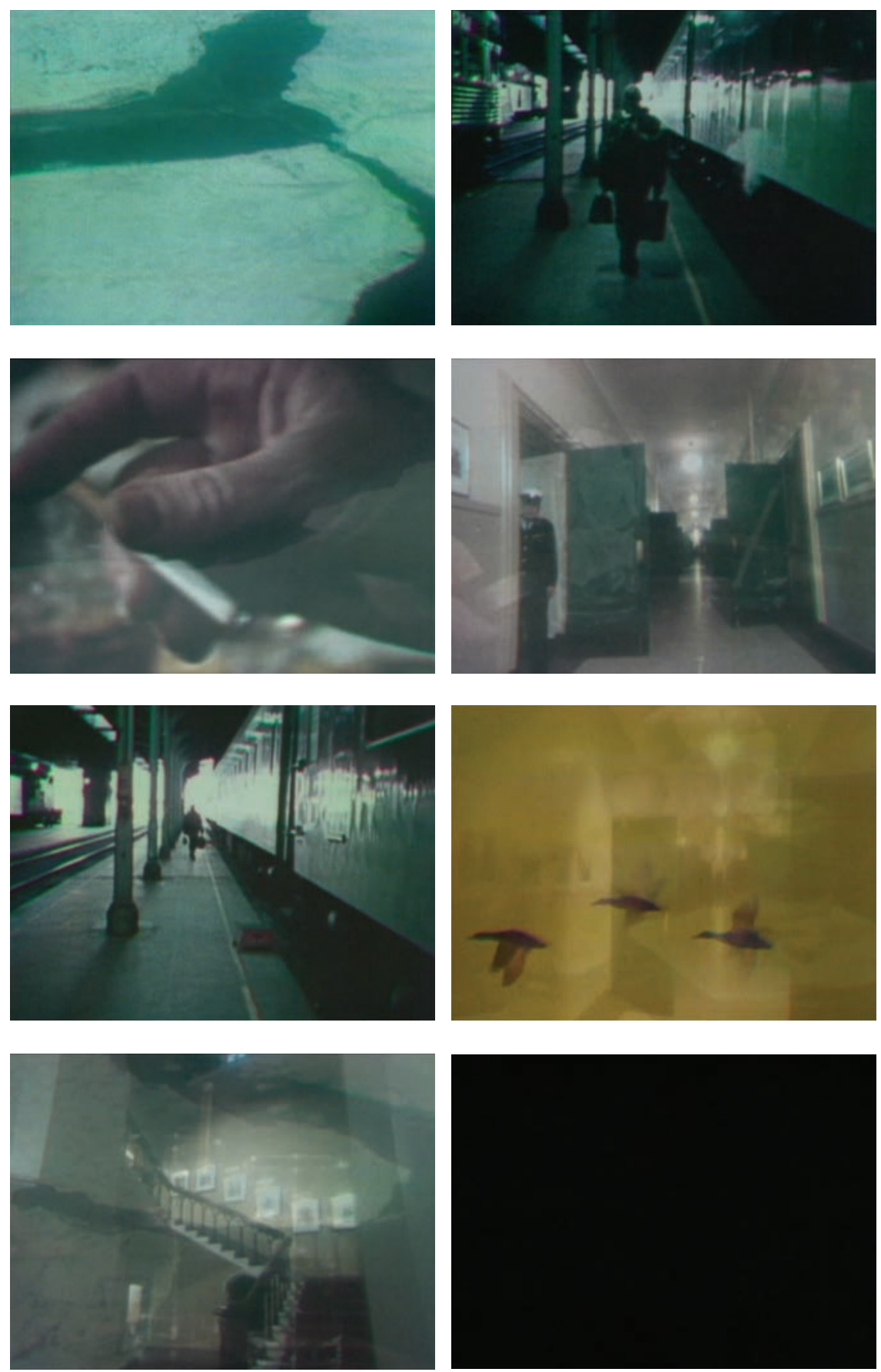

From the prologue to The Idea of North (directed by Judith Pearlman, script and sound: Glenn Gould, coproduction: CBC and National Education Television 1970) (C) CBC. 